\title{
NATIONAL COMPETITIVENESS THROUGH THE EUROPE 2020 STRATEGY AND HUMAN DEVELOPMENT INDEX IN CEE COUNTRIES. A PANEL DATA ANALYSIS
}

\begin{abstract}
Ana Maria TALMACIU1, Laura Mariana CISMAS²
DOI: $10.1515 /$ tjeb-2016-0008

In the new innovation economy, national competitiveness is an expression of the quality of the human capital and of the capacity to attract and retain the talent. In this paper, we propose to verify the link between the national competitiveness and the human capital, measured by the public expenditure on tertiary education and by the public expenditure on research and development. The research methodology uses the Panel Data method for Central and Eastern European countries by analyzing data on competitiveness scores in the Europe 2020 Report 2014, the Human Development Index 2015, the Global Competitiveness Report 2016 and those on public expenditure on tertiary education and by the public expenditure on research and development, corresponding to the period 2010-2014. The objectives of this paper are: synthesis of theoretical delimitations on competitiveness, highlighting the relationship between national competitiveness and human capital, testing this relationship for the case of Central and Eastern European countries. The results show a significant and a positive relation, indicating that investment in education and research contributes significantly to increasing the national competitiveness. The obtained results draw attention to the fact that Central and Eastern Europe countries need to initiate measures to reduce the drain-brain phenomenon and to create a favorable socio-economic context for retaining and attracting the talent.
\end{abstract}

Keywords: Competitiveness, Human capital, Education, Panel data analysis

JEL Classification: 125, 131, C23

${ }^{1}$ PhD Student, West University of Timisoara, Faculty of Economics and Business Administration, Romania.

2 Professor PhD, West University of Timisoara, Faculty of Economics and Business Administration, Romania. 
Talmaciu A.M, Cismas L.M. (2016).

National competitiveness through the Europe 2020 strategy and human development index in CEE countries. A panel data analysis

\section{Introduction}

The dynamics of the global economy, the speed of the human evolution and the increased aspirations for higher standards of living, have determined the concerns on the possible solutions for economic progress and civic welfare. Thus, competitiveness has become the binder of many social, economic and political factors, which enhance the ability of nations to produce and to distribute the welfare among their population.

Competitiveness is one of the largest and most debated concepts in the contemporary economy, due to the multitude of meanings and interactions that define it. At the theoretical level, competitiveness does not have a precise meaning, unanimously accepted. Over time, scientific debates have put the equal sign between competitiveness and productivity, growth and economic development, national wealth, globalization, sustainable development or ability to sell national economic goods on international markets.

The origin of the concept of competitiveness is in the theory of foreign trade, but the economic development has expanded its features in relation to the rapid changes in technology, the scale of globalization and economic liberalization.

Currently, the world economy is under this "race test" called competitiveness. The world states are seeking to capitalize on the unique factors that can lead to an increased level of well-being.

The current trends in the global economy show that focusing efforts to improve the quality of human capital is the optimal solution for progress towards the new innovation economy. In this regard, the importance of the human factor in determining the share of the competitive level of nations has increased significantly. As innovations increase market competitiveness, the national competitiveness level increases too. The source innovation is the human factor and the investment in his education, and research and development ensure a greater competitive potential.

Given the fact that the Europe 2020 Strategy focuses on the importance of human capital in four out of the five objectives for increasing competitiveness, we consider that Central and Eastern European countries need to make further efforts to achieve the national targets and to increase the quality of the labor force. In other respects, the importance of this concern lies in the fact that quality of the labor force, education and the innovative potential are the future leading vectors of the national competitiveness. In this respect, the present paper is a further proof of this fact, and it also has the role of highlighting the possible benefits as a result of increasing human capital through all the aspects that characterize it.

In order to achieve the proposed objectives, the paper concentrates the topics of national competiveness, human capital and national competitiveness scores in two main parts. The first part of the paper puts the foreground the main approaches of the national competitiveness and reveals its plurivalent character from the influence factors perspective. The European Competitiveness Strategy 2020 is presented briefly in the light of its strategic priorities and from

DE GRUYTER OPEN
116

Timisoara Journal of Economics and Business | ISSN: 2286-0991 | www.tjeb.ro Year 2016 | Volume 9 | Issue 2 | Pages: 115-128 
Talmaciu A.M, Cismas L.M. (2016).

National competitiveness through the Europe 2020 strategy and human development index in CEE countries. A panel data analysis

the human capital vision. The link between national competitiveness and human capital is highlighted by the characterization of the Human Development Index, its components and the links between them.

The second part of the paper examines the relations between the competitiveness scores of the Central and Eastern European countries in the Europe 2020 Report 2014, the Human Development Index 2015, the Global Competitiveness Report 2016 and the data on the public expenditure on tertiary education and by the public expenditure on research and development, corresponding to the 2010-2014 period.

The last section of the paper discusses the results obtained and offers some future research lines on how human capital, through all its components, influences the national competitiveness.

\section{Multicriterial Approaches Of Competitiveness}

The economic debates had always the aim to identify the opportunities of economic efficiency growth of a nation, even if it did not always have a precise reference to the term of competitiveness. The need for competitiveness in a market-based economy is a stringent one, competition being an important part of the economic activity. The economic integration and the globalization have involved a permanent development of the competitive power, thus competitiveness having an increasingly larger importance and a complex significance.

The concept of competitiveness did not receive a unanimous or uniform approach. This has led to increasing the concept complexity and to its multidimensional understanding. Offering some exhaustive definitions and criticism of the concept is a difficult task, given its numerous approaches.

The academic definitions highlight some of the main delimiting lines of the concept: a) competitiveness as productivity; b) competitiveness as the ability of nations to enter the international competition in terms of trade; c) competitiveness as a nation's welfare; d) competitiveness as a social and economic objective.

In a general sense, competitiveness is defined as "the capacity of a country, measured by comparison with other countries, to train and to ensure an economic, social and political level to support the creation of added value" (Pauna, Iordan, Chilian, 2013). Hence, national competitiveness must be treated "in relative and not in absolute terms" (Berger, 2008), just so it can be "a basis for comparison" (Berger, 2008) for other nations.

In relation to productivity, competitiveness is "a set of institutions, policies and factors that determine the productivity of the country" (WEF, 2009), measured by the share of these indicators in the national economy, or "a way of expressing the aspiration for prosperity and productivity a country "(WCY, 2015).

DE GRUYTER OPEN
Timisoara Journal of Economics and Business | ISSN: 2286-0991 | www.tjeb.ro Year 2016 | Volume 9 | Issue 2 | Pages: 115-128 
Talmaciu A.M, Cismas L.M. (2016).

National competitiveness through the Europe 2020 strategy and human development index in CEE countries. A panel data analysis

Pair sense of competitiveness and productivity is seen in the works of Porter, Krugman or Kohler. In Porter's view, the productivity plays a decisive role in training all the determinants of competitiveness, both at the micro and macro level.

At the same time, Krugman believes that the potential of "a country's ability to improve, while living conditions, depends almost entirely on the ability to increase the production per worker" (Krugman, 2004).

Kohler understands competitiveness as the absolute level of productivity, which generates welfare of a nation, international trade contributing in this direction.

Competitiveness as the ability of the nations to enter the international competition trade has been defined as:

- "Competitiveness in terms of international trade, measure the advantages and disadvantages of a country in the process of selling goods on international markets" (Organisation for Economic Co-operation and Development, 2016);

- "Competitiveness is the ability of companies, sectors, regions competing internationally to ensure a sustained income from the relatively high capitalization of labor" (OECD, 2012);

At the same time, competitiveness has been defined also in terms of ability to create national wealth. Thus, Karl Aiginger treats competitiveness as "the ability to create wealth" and evaluate it "in sense of results" (outcome competitiveness) and in "sense of processes" (process Competitiveness) (Aiginger, 2006). Outcome competitiveness concerns the welfare of a nation characterized by low income per capita, by social indicators and the distribution size, and by a set of environmental indicators. Process competitiveness is defined by quantitative and qualitative factors that generate it, emphasizing the physical capital, labor, the technological progress, the institutions quality and their confidence level.

This approach is also found in Porter's works: "Competitiveness is the ability of an economy to provide a high standard of living of its citizens" (Porter, 2001).

Lastly, competitiveness is defined by its economic and social objectives whose achievement is felt among the population, as standards of living.

Thus, the "competitiveness (...) determines how countries, regions, and companies manage their competencies to achieve long-term growth, and to generate jobs. Competitiveness is, therefore, a path towards progress, which does not end with winners and losers: when two countries compete, both win"(IMD, 2012).

In a more concrete way, competitiveness is "a way to create jobs and to eradicate the poverty" (Competitiveness Advisory Group - Ciampi Group, European Enhancing Competitiveness, The First Report of the President of National Competitiveness Council of Ireland, 1988).

As shown, the general definitions particularly related to the potential to generate national prosperity, higher standards of living and international trade performance. However, the

DE GRUYTER OPEN 
Talmaciu A.M, Cismas L.M. (2016).

National competitiveness through the Europe 2020 strategy and human development index in CEE countries. A panel data analysis

literature argues that the notion of competitiveness is "amorphous" (Porter, 1990) that relates strictly to economic prosperity, not what determines it.

Economic dynamics of a country is in total dependence on the resources that it has at one time. If technological, material, natural and financial factors, constantly help fuel the economy, human capital is the factor that determines the size of these factors, and their productivity.

Human capital - economic growth relationship is rooted in the works of Adam Smith (1776) and Karl Marx. Although it doesn't provide a concrete way of estimating the value of human capital, Adam Smith (1776) stated in his "Wealth of Nations, that "the country is rich if it has wealthy/ educated individuals", citing that "the improvement of knowledge is a factor of economic progress". In Smith's view, technical capital is and remains resultant human capital, being tangible and measurable; Marx places the value analysis and value creative work out of the qualitative parameters.

Spending on education can be seen both as an investment as well as consumption. Border demarcation between investment and consumption has preoccupied economists (Kiker, 1971, Mincer, 1993; Schultz, 1993), without leading to a total consensus. In general, it was found that human capital treatment and investment, human capital skills can be used virtually anytime, depending on the social and economic environment in which individuals can place at a certain time. Recent studies (Pavlovic, Ljumovic, 2016) focus on investments in young people, through education and work skills, as a priority for achieving a better labor market efficiency and a stronger national competitive potential. Also, the innovative national potential, as a consequence of a high-performance education system, is essential for the sustainable competitiveness of a nation in the context of the characteristics of the current economy (Carayannis, Grigoroudis, 2016).

The most obvious results of the link between education and economic growth comes from studies of Sianesi and Van Reenen (2002); They highlighted the fact that increasing primary school enrollment by $1 \%$, leads to a gross domestic product increase by $2 \%$ in less developed countries; the results showed the same in the case of developed countries. The same study revealed that employees with a higher level of education have a greater impact on the company productivity level. Highly qualified employees generate an abundance of knowledge in the company, thereby it increases its capacity for innovation.

\section{The European Strategy For Competitiveness}

At The European Union level, the policy of increasing the competitiveness involves reaching the national targets set in the Europe 2020 strategy.

Launched in 2010 under the official name 2020: A European strategy for smart, sustainable and inclusive growth, the European program projected the main areas which contribute to economic growth and social development in the context of the innovation economy.

DE GRUYTER OPEN

119
Timisoara Journal of Economics and Business | ISSN: 2286-0991 | www.tjeb.ro Year 2016 | Volume 9 | Issue 2 | Pages: 115-128 
Talmaciu A.M, Cismas L.M. (2016).

National competitiveness through the Europe 2020 strategy and human development index in CEE countries. A panel data analysis

The strategy has three interdependent priorities:

- Smart growth: developing an economy based on knowledge and innovation.

- Sustainable growth: promoting a more efficient economy in terms of resource use, greener and more competitive.

- Inclusive growth: promoting an economy with a high rate of employment, ensuring social and territorial cohesion.

The European strategy for increasing competitiveness, sits in the foreground the human capital factor in two ways: directly, through four objectives: increasing the employment rate, reducing early school leaving, increase the number of the university graduates, reducing the number of people at risk of poverty and social exclusion; indirectly, by the objective of increasing the public expenditure on research and development up to at least 3\% of GDP.

The global trends on sustainable development have led to the finding that innovation plays the main role in upgrading the technology and the production processes, and also in the creation of a competitive production system. Based on knowledge and creative ideas, the current economy becomes the innovation economy, as a necessary step for the evolution of the nations.

The characteristics the innovational economy are: high level of education and science, high level of economic freedom, high weight of the innovational enterprises (over $60 \%$ of the national enterprises), increased competition in innovation, high living standards, human capital quality.

In this context, the role of the human capital through its innovative capacity, triggers national competitiveness, in the new features of the world economy.

From this perspective, the Europe 2020 Strategy focuses its objectives, investment in education and research and development activities, in order to create a favorable environment for innovative activity in competition conditions.

\section{Human Development Index}

In 1990 the economist Mahbub UI Haq initiated the first Human Development Report in order to express the "richness of human life", rather than "the richness of the economy in which human beings live".

Its purpose is to measure the main components that influence the quality of human life and the national living standards. The measure of these components is given by the Human Development Index, resulted in the following indicators: a long and healthy life, access to knowledge and a decent standard of living.

The HDI is the geometric mean of the three-dimensional indices: $\mathrm{HDI}=$ (Health, Education, Income). The HDI results range between 0 and 1,1 being the best and 0 the worst human development human development.

DE GRUYTER OPEN
Timisoara Journal of Economics and Business | ISSN: 2286-0991 | www.tjeb.ro Year 2016 | Volume 9 | Issue 2 | Pages: 115-128 
Talmaciu A.M, Cismas L.M. (2016).

National competitiveness through the Europe 2020 strategy and human development index in CEE countries. A panel data analysis

The role of the human capital on national competitiveness is a widely debated theme in the literature, considering several directions: the importance of the education (Smith, 1776 Blaug, 1976, Siannesi, Reenen, 2012), efficiency of the expenditure on education (Schultz 1961, Becker 1964, Mincer, 1970), the relationship between the education and the income levels (Hanushek, Woessman, 2007, 2008, 2011, Barro, Lee, 1993) the relationship between the education and the national capacity to attract foreign direct investment (Mugal, Vechiu, 2011, Lowell, Findley, 2001, Yussof Ismail, 2002, Hanushek, 2016, Badea, 2014, Pelinescu, 2015).

A significant contribution in this regard has Jacob Mincer, by demonstrating the relationship between the economic growth and the human capital, regarded as "a stock of skills and knowledge" (Mincer, 1975, p. 71). It concludes that "the only cost of an additional year of school is the expected return, thus ignoring the direct costs such as tuition fees" (Mincer, 1975, p. 7478). In the same direction are T. Schultz's analyzes, for which "knowledge is a separate economic value" and the science itself "is a rational activity designed only for those enough trained to understand it" (Liana Badea, Angela Rogojanu, 2015, p.24).

Recognized for numerous works dedicated to the description of the human capital value, Hanuschek reiterates the fact that the differences between the human capital are closely related to differences in the growth rates of nations. It highlights the impact of competitive human resources on economic growth, taking into account factors such as higher education, vocational skills and talents (Eric Hanuschek, 2016, p. 12).

Given the economist's demonstrations who have analyzed the human capital impact on the national economy, it is inferred that human resources are the first factor that enhances the effectiveness of all other determinants of competitiveness.

\section{Panel Data Analysis - CEE countries}

The Countries of Central and Eastern Europe (CEE) are considered an inhomogeneous group regarding the economic and social environment but also in terms of interim results in the Europe 2020 Strategy's goals achievements.

Precisely for this reason, the EEC Countries were selected to detect the extent of the relationship between the national competitiveness and the human capital.

\section{Research methodology and data}

The selected data for analysis correspond to the 2010-2014 period (Eurostat Platform), 2010 being the year in which Europe 2020 Strategy was initiated, and 2014, the last year for which data are available.

The variables considered for testing the connection are oriented on the input factors: Expenditure on tertiary education (EDET), Gross expenditure on Research and Development, as

DE GRUYTER OPEN
Timisoara Journal of Economics and Business | ISSN: 2286-0991 | www.tjeb.ro Year 2016 | Volume 9 | Issue 2 | Pages: 115-128 
Talmaciu A.M, Cismas L.M. (2016).

National competitiveness through the Europe 2020 strategy and human development index in CEE countries. A panel data analysis

a percentage of GDP (GERD). The dependent variable is the Human Development Index (HDI), for the same period, 2010 - 2014.

For testing the relationship, we used the Panel Data Cross Sections method.

The estimated equation of the variables can be written:

$$
H D I_{i t}=\alpha+\beta_{1} E D E T_{i t}+\beta_{2} G E R D_{i t}
$$

Where, Cross section (Estonia, Slovenia, Lithuania, Czech Republic, Latvia, Poland, Hungary, Romania, Slovakia, Bulgaria); $\mathrm{t}$ - time period (2010-2014); $\alpha$ - intercept; $\beta_{1}, \beta_{2}$-coefficients

To test the relation between the competitiveness and the expenditure on education and on research and development, we used E-Views software. The obtained results are (Annex):

$$
H D I_{i t}=74.41+4.97 E D E T_{i t}+3.12 G E R D_{i t}
$$

The resulted value of the $R^{2}$ is 0.78 , while the value of adjusted $R^{2}$ is 0.76 , which means that the relationship between competitiveness and the expenditure on education and on research and development is very strong. The model and the variables are significant at $5 \%$ significance level. This means that an increase of the expenditure on tertiary education and on research and development leads to an increase of the national competitiveness. Having these results, we can say that encouraging the education and fighting against the drop out early school, the labor market will become more specialized and efficient. High rate of tertiary educations are able to attract the foreign investors and raise the quality of life for the other citizens.

\section{Human Capital impact on national competitiveness in Europe 2020 Strategy, Human Development Index and The Global Competitive Report}

To double check the relation between competitiveness and the analysed variables, we tested the Pearson coefficient between the country ranks in the Europe 2020 Strategy Report 2014 and the Human Development Index 2014.

Table 1. The correlation between country ranks in the 2020 Europe Strategy and the Human Development

\begin{tabular}{lccccc}
\hline & N & Pearson & $\mathbf{R}^{\mathbf{2}}$ & $\mathbf{p}$ & P Value \\
\hline $\begin{array}{l}\text { 2020 Europe Strategy rank and } \\
\text { Human Development Index rank }\end{array}$ & 10 & 07891 & 0.6226 & $<0.01$. & 0.007 \\
\hline
\end{tabular}

Source: own calculations

Going further, we have tested the relation between the country ranks in the Europe 2020 Strategy 2014, the Human Capital Index 2014, and the country ranks in the Global

DE GRUYTER OPEN
Timisoara Journal of Economics and Business | ISSN: 2286-0991 | www.tjeb.ro Year 2016 | Volume 9 | Issue 2 | Pages: 115-128 
Talmaciu A.M, Cismas L.M. (2016).

National competitiveness through the Europe 2020 strategy and human development index in CEE countries. A panel data analysis

Competitiveness Report 2014. The results confirmed that there is a strong positive correlation between them, meaning that the human capital is the current trigger for the national competitiveness.

Table 2. The correlation between country ranks in the Europe 2020 Strategy and the Global Competitiveness Report and the Human Development Index

\begin{tabular}{lccccc}
\hline & $\mathbf{N}$ & Pearson & $\mathbf{R}^{\mathbf{2}}$ & $\mathbf{p}$ & P Value \\
\hline $\begin{array}{l}\text { 2020 Europe Strategy rank } \\
\text { and Global Competitiveness } \\
\text { Report }\end{array}$ & 10 & 0.6398 & 0.4093 & $<0.05$ & 0.04 \\
\hline $\begin{array}{l}\text { The Human Development } \\
\begin{array}{l}\text { Index and the Global } \\
\text { Competitiveness Report }\end{array}\end{array}$ & 10 & 0.6398 & 0.4093 & $<0.05$ & 0.04 \\
\hline
\end{tabular}

Source: own calculations

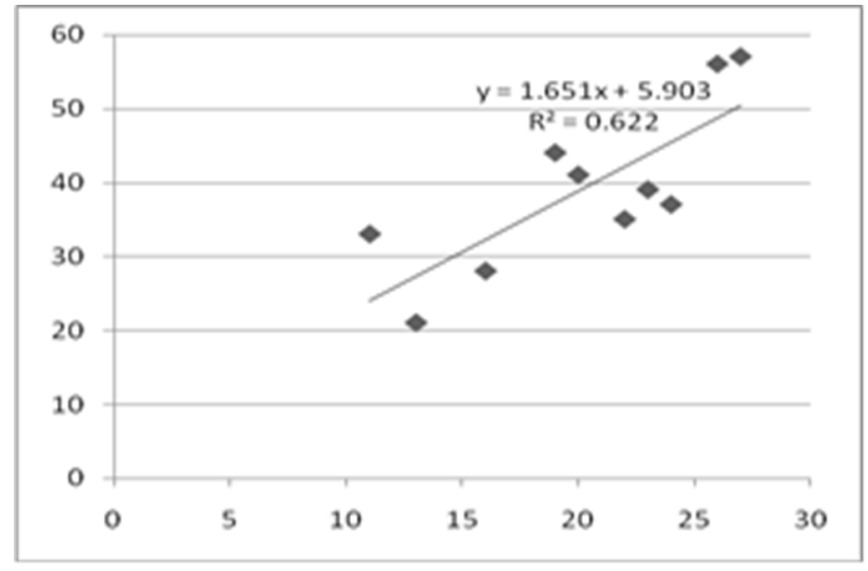

Figure 1. The Human Development Index and Europe 2020 Strategy

Source: own calculations

For the correlation between the Human Development Index and the Europe 2020 Strategy, the Pearson value is 0.78 and the $\mathrm{R}^{2}$ value is 0.622 , highlighting a strong and a direct connection. This means that improving the HDI score leads to a more favorable ranking score of interim results regarding the progress in achieving the Europe 2020 objectives. 
Talmaciu A.M, Cismas L.M. (2016).

National competitiveness through the Europe 2020 strategy and human development index in CEE countries. A panel data analysis

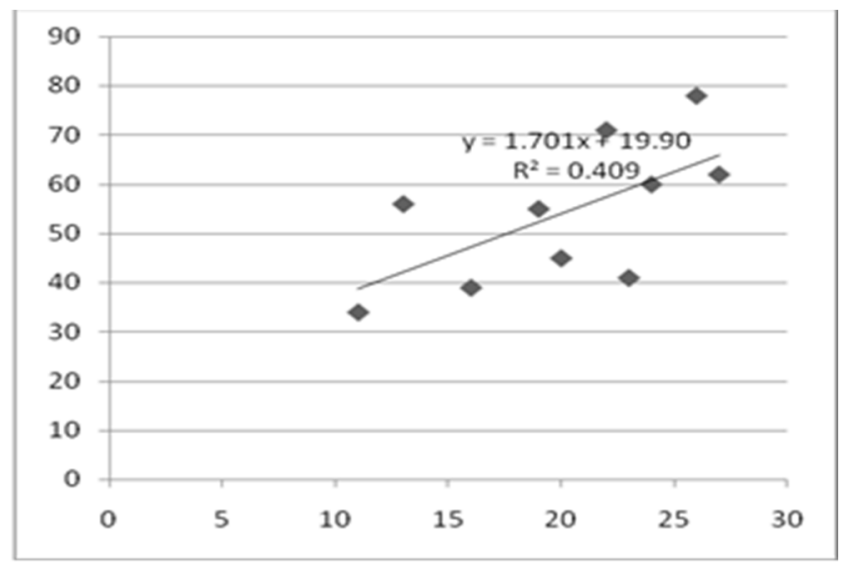

Figure 2. The Global Competitiveness Report and Europe 2020 Strategy

Source: own calculations

Correlating the countries ranks between the Global Competitiveness Report and the Europe 2020 Strategy we discover a positive connection, with the Pearson value of 0.63 , and the $\mathrm{R}^{2}$ value, 0.409. The Global Competitiveness Report contains 12 pillars, of which human capital (education and investment in research and development) is found in 5 of them (Pillar 1. Public and private quality institutions; Pillar 5. Higher education and training; Pillar 7. Labor market efficiency; Pillar 9. Technology, Pillar 12. Innovation).

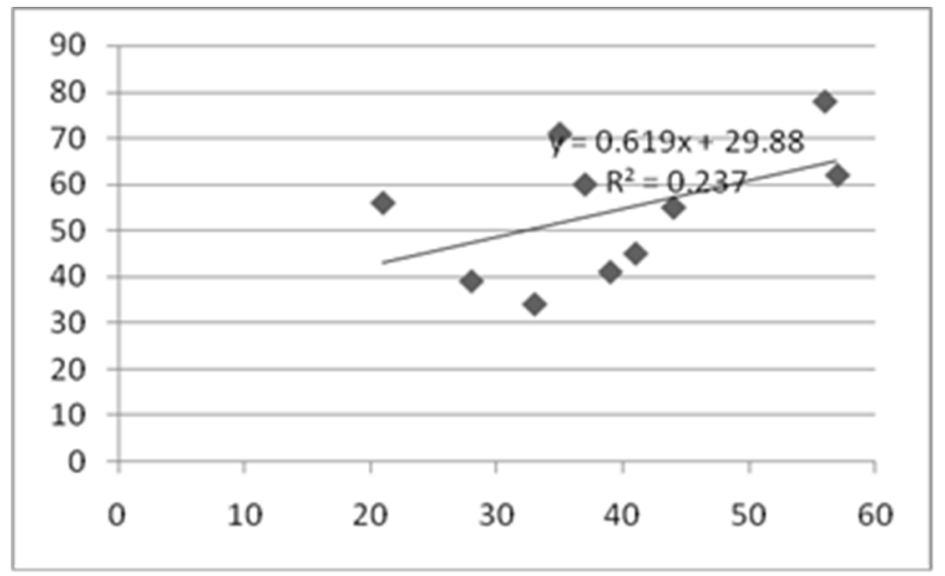

Figure 3. The Global Competitiveness Report and the Human Development Index

Source: own calculations

DE GRUYTER

\section{OPEN}

Timisoara Journal of Economics and Business | ISSN: 2286-0991 | www.tjeb.ro

Year 2016 | Volume 9 | Issue 2 | Pages: 115-128 
Talmaciu A.M, Cismas L.M. (2016).

National competitiveness through the Europe 2020 strategy and human development index in CEE countries. A panel data analysis

In the last test, the relation between the country ranking in the Global Competitiveness Report and the Human Development Report is weaker than the other ones, with the Pearson value, 0.48 , and the $\mathrm{R}^{2}$ value, 0.23 . This fact can be explained trough the fact that the Global Competitiveness Index contains many macroeconomic indicators, not reflected in the Human Development Report. Even so, there is a positive relation between them, meaning that the human capital factor, through education and its innovative potential, has a major impact on the national competitiveness.

\section{Conclusions}

Although many studies have demonstrated the strong relationship between the national competitiveness and the human capital, expressed through the level and the quality of education, its effects become visible over a long period of time. From this point of view, this paper is limited by the reduced number of years under observation, as well as by the fact that the analyzed states are in the process of economic development. As a future direction for research on the impact of higher education and $R \& D$ investment on national competitiveness, it can be mapped around one or more countries that have made their mark in this direction, such as Sweden or Finland.

The national capacity to improve the quality of the human capital significantly influences the national competitiveness and welfare. The investments in tertiary education, in research and development and in infrastructure technology are the main determinants of the innovation economy where we currently are.

Through the Europe 2020 Strategy's objectives, the EU highlights their impact on growth and living standards of citizens, and also on the sustainable development. The competitive capacities of the CEE countries register different, but the impact of the human factor turns out to be as powerful for all of them. The CEE countries should focus more on the investment in higher education (Bulgaria, Romania and Latvia) and in the research and development (Romania, Bulgaria, Slovakia, Poland). Also, the analysed model states that achieving the Europe 2020 objectives leads to a better positioning in the rankings of the Global Competitiveness Report and the Human Development Index. From this point of view, Romania has a great opportunity to meet the tertiary education target, based on the current interim results. It depends on the measures of the officials and the initiatives of the society, the way in which this opportunity will be valorised and quantified in a competitive national advantage.

DE GRUYTER OPEN 
Talmaciu A.M, Cismas L.M. (2016).

National competitiveness through the Europe 2020 strategy and human development index in CEE countries. A panel data analysis

\section{Appendix}

Appendix 1. Model Summary c

\begin{tabular}{|c|c|c|c|c|c|c|c|c|c|c|}
\hline \multirow[b]{2}{*}{ Model } & \multirow[b]{2}{*}{$\mathbf{R}$} & \multirow{2}{*}{$\begin{array}{c}\mathbf{R} \\
\text { Square }\end{array}$} & \multirow{2}{*}{$\begin{array}{l}\text { Adjusted R } \\
\text { Square }\end{array}$} & \multirow{2}{*}{$\begin{array}{l}\text { Std. Error of the } \\
\text { Estimate }\end{array}$} & \multicolumn{5}{|c|}{ Change Statistics } & \multirow{2}{*}{$\begin{array}{l}\text { Durbin- } \\
\text { Watson }\end{array}$} \\
\hline & & & & & $\begin{array}{c}\text { R Square } \\
\text { Change }\end{array}$ & $\begin{array}{c}\mathbf{F} \\
\text { Change }\end{array}$ & df1 & df2 & $\begin{array}{l}\text { Sig. F } \\
\text { Change }\end{array}$ & \\
\hline 1 & $.826 a$ & .682 & .675 & 1.74773 & .682 & 102.721 & 1 & 48 & .000 & \\
\hline 2 & $.886 b$ & .785 & .776 & 1.45066 & .104 & 22.672 & 1 & 47 & .000 & .747 \\
\hline
\end{tabular}
a. Predictors: (Constant), GERD
b. Predictors: (Constant), GERD, EDET
c. Dependent Variable: HDI

\section{Appendix 2. ANOVA a}
a. Dependent Variable: HDI
b. Predictors: (Constant), GERD
c. Predictors: (Constant), GERD, EDET

\begin{tabular}{|c|c|c|c|c|c|c|}
\hline \multicolumn{2}{|c|}{ Model } & Sum of Squares & df & Mean Square & F & Sig. \\
\hline 1 & Regression & 313.766 & 1 & 313.766 & 102.721 & $.000^{\mathrm{b}}$ \\
& Residual & 146.619 & 48 & 3.055 & & \\
& Total & 460.385 & 49 & & & \\
\hline 2 & Regression & 361.477 & 2 & 180.739 & 85.885 & $.000^{\circ}$ \\
& Residual & 98.908 & 47 & 2.104 & & \\
& Total & 460.385 & 49 & & & \\
\hline
\end{tabular}

Appendix 3. Coefficients a

\begin{tabular}{|c|c|c|c|c|c|c|}
\hline & \multirow{2}{*}{ Model } & \multicolumn{2}{|c|}{ Unstandardized Coefficients } & \multirow{2}{*}{\begin{tabular}{|c|} 
Standardized Coefficients \\
Beta
\end{tabular}} & \multirow{2}{*}{$\mathbf{t}$} & \multirow{2}{*}{ Sig. } \\
\hline & & B & Std. Error & & & \\
\hline \multirow[t]{2}{*}{1} & (Constant) & 78.493 & .513 & & 152.940 & .000 \\
\hline & GERD & 3.981 & .393 & .826 & 10.135 & .000 \\
\hline \multirow[t]{3}{*}{2} & (Constant) & 74.417 & .956 & & 77.823 & .000 \\
\hline & GERD & 3.123 & .373 & .648 & 8.381 & .000 \\
\hline & EDET & 4.980 & 1.046 & .368 & 4.762 & .000 \\
\hline
\end{tabular}

a. Dependent Variable: HDI

DE GRUYTER OPEN 
Talmaciu A.M, Cismas L.M. (2016).

National competitiveness through the Europe 2020 strategy and human development index in CEE countries. A panel data analysis

\section{References}

Aiginger, K.(2006). Revisiting an Evasive Concept: Introduction to the Special Issue on Competitiveness, Journal of Industrial Competitiveness and Trade 6:63-66, DOI: 10.1007/s10842-006-9471-x, Springer Science - Business Media, LLC 2006

Badea A., Rogojanu A.(2012). Controversies concerning the connection higher education human capital - competitiveness, Theoretical and Applied Economics Volume XIX (2012), No. 12(577), pp. 125-142

Barro R., J. (2001). Human Capital and Economic Growth. American Economic Review,91(2), pp.12-17.

Berger T. (2008). Concepts Of National Competitiveness, Journal of International Business and Economy 9(1): 91-111

Carayannis, E., G., Evangelos G. (2016). Using multiobjective mathematical programming to link national competitiveness, productivity, and innovation, Annals of Operations Research 247.2 pp. 635-655

Hanuschek A. E.(2016). Will More Higher Education Improve Economic Growth?,Oxford Review for Economic Policy, Vo. 32, I. 4, DOI: https://doi.org/10.1093/oxrep/grw025

Krugman P. (1994). The Age of Diminished Expectations, Third Edition: U.S. Economic Policy in the 1990s, The Washington Post Company, 1997

Mincer J. (1970). The Dostribution of labor incomes: A Survey With Special reference to the Human capital Approach, Journal of Economic Literature

Mugal M., Vechiu N. (2011)/ The Role Of Foreign Direct InvestmentIn Higher Education In The Developing Countries(Does Fdi Promote Education?), Centre d'Analyse Théorique et de Traitement des données économiques, CATT WP No. 10.February 2011

Pavlović, D., Ljumović, I. (2016). Competitiveness Index Analysis: Is Investing in Young People Important for Achieving National Competitiveness? Economic Analysis, 49 (1/2). pp. 24-35

Păuna C. B., Iordan M., Chilian M., N.(2013). Competitiveness And Innovation In Regions Of Romania - What Progress Has Been Made In Post-Accession Period?, The USV Annals of Economics and Public Administration, Volume 15, Issue 1(21), 2015, 133141

Porter M. (2001). The Competitive Advantage of Nations, The Free Press, 1990

Sianesi B., Reenen J. V. (2000). The Returns to Education: A Review of Macro-Economic Literature, Centre for the Economics and Education, LSE

Schultz T. (1961). Investment in Human Capital, The American Economic Review, Vol 51, No 1

Yussof I., Ismail R. (2002). "Human Resource Competitiveness and Inflow of FDI to the Asean Region", in Asia-Pacific Development Journal, Vol. 9, No. 1, June 2002

Organisation for Economic Co-operation and Development, Competitiveness in South East Europe, OECD Publishing, 2016

Competitiveness Advisory Group- Ciampi Group, European Enhancing Competitiveness, The First Report of the President of National Competitiveness Council of Ireland, 1988 
Talmaciu A.M, Cismas L.M. (2016).

National competitiveness through the Europe 2020 strategy and human development index in CEE countries. A panel data analysis

European Commision, The Europe 2020 Strategy, availible at https://ec.europa.eu/info/strategy/european-semester/framework/europe-2020strategy_en

World Economic Forum, The Europe 2020 Competitiveness Report, available at http://www3.weforum.org/docs/WEF_Europe2020_CompetitivenessReport_2014. pdf

World Economic Forum, The Global Competitiveness Report 2014, available at http://www3.weforum.org/docs/WEF_GlobalCompetitivenessReport_2014-15.pdf

United Nations Development Programme, the Human Development Index database, available at http://hdr.undp.org/en/content/human-development-index-hdi 